\title{
UPAYA MENINGKATKAN HASIL BELAJAR ANALISIS RATIO KEUANGAN DENGANMENGGUNAKAN MODEL PEMBELAJARAN SCOFFOLDING PADA PROGRAM STUDI AKUNTANSI FKIP UMSU
}

\author{
Fatmawarni \\ Program Studi Pendidikan Akuntansi Fakultas keguruan dan Ilmu Pendidikan UMSU \\ Fatmawarni010@gmail.com
}

\begin{abstract}
Abstrak
Penelitian ini bertujuan untuk meningkatkan kualitas pembelajaran dengan mengembangkan pembelajaran Analisa laporan keuangan dengan model Scoffolding, dengan model scoffolding ini mahasiswa dituntut untuk dapat beraktivitas, dalam mengerjakan persoalan analisis laporan keuangan dengan bantuan dan bimbingan dari dosen, pada awalnya dan kemudian secara perlahan-lahan mahasiswa tersebut akan mandiri dan bertanggung jawab terhadap tugas maupun persoalan akuntansi. Persoalan tersebut diawali dengan rendahnya hasil belajar analisa laporan keuangan hal tersebut disebabkan karena mahasiswa kurang memahami konsep akuntansi, dan merasa kurang bersemangat dalam menyelesaikan tugas-tugas yang diberikan, selain hal tersebut selama ini pembelajaran hanya berdasarkan target kurikulum. Penelitian ini menggunakan metode tindakan kelas yaitu suatu metode yang melakukan penerapan pembelajaran dikelas mulai dari perencanaan, pelaksanaan tindakan, Observasi dan melakukan refleksi. Dalam hal ini peneliti mencoba penerapan langsung terhadap pembelajaran yang akan dilakukan dengan mengunakan model pembelajaran Scoffolding. Dengan objek penelitian adalah mahasiswa semester tujuh yang mengambil mata kuliah Analisa laporan keuangan, berjumlah 40 orang mahasiswa. Instrumen yang digunakan adalah dalam bentuk lembar observasi, yang berisi indikator pengamatan yang berhubungan dengan aktivitas mahasiswa, dengan teknik analisis Deskriptip. berdasarkan hasil analisis yang dilakukan kepada 40 orang masiswa yang mencapai diatas kategori tinggi sebanyak $80 \%$ dan nilai ratarata kelas 81 , artinya ada peningkatan hasil belajar dengan menggunakan model pembelajaran Scoffolding.
\end{abstract}

\section{Kata Kunci: Model Scoffolding, scientifik.}

Abstract
This study aims to improve the quality of learning by developing learning Financial
statement analysis with the Scoffolding model, with this scoffolding model students are
required to be able to move, in working on financial statement analysis issues with the
help and guidance of lecturers, initially and then slowly the student will be
independent and responsible for accounting tasks and issues. The problem begins with
the low learning outcomes of financial statement analysis because it lacks
understanding of the concept of accounting, and feels less eager to complete the
assignments given, besides this, learning has only been based on curriculum targets.
This research uses the class action method, which is a method that implements


Liabilities Jurnal Pendidikan Akuntansi

e-ISSN 2620-5866

Volume 2. No.3 Desember 2019 (186-200)

Doi 10.30596/liabilities.v2i3.3770

learning in the classroom starting from planning, implementing actions, observing and reflecting. In this case the researchers tried the direct application of learning to be done by using the Scoffolding learning model. The object of research is the seventh semester students who take the Financial Statement Analysis course, totaling 40 students. The instrument used was in the form of an observation sheet, which contained observational indicators related to student activities, with descriptive analysis techniques. based on the results of an analysis of 40 students who reached above the high category of $80 \%$ and an average grade of 81, meaning that there was an increase in learning outcomes using the Scoffolding learning model.

Keywords: Scoffolding Model, scientific

\section{PENDAHULUAN}

Pembelajaran Analisa ratio keuangan adalah bahagian dari analisa laporan keuangan yang merupakan bahagian dari disiplin ilmu yang berhubungan dengan pengukuran, penjabaran dan memberikan kepastian mengenai informasi yang akan membantu para menejer dalam pengambilan keputusan baik untuk dalam perusahaan maupun luar perusahaan. Informasi tersebut dapat dituangkan melalui penyajian laporan keuangan. Untuk membuat laporan keuangan yang baik tentu memerlukan sumber daya yang relevan dengan ilmu akuntansi, Proses penyusunan laporan keuangan tersebut diawali dengan proses pencatatan yang bersumber dari bukti dokumen transaksi, Bukti dokumen transaksi merupakan aktivtas ekonomi yang terjadi pada perusahaan, dari bukti dokumen tersebut, dianalisis dan dicatat dalam perusahaan dalam buku harian yang disebut dengan menjurnal, atau menentukan akun debit dan akun kredit.Menurut harnanto (2002) untuk menyajikan laporan keuangan sebagai informasi ada tahapan -tahapan yang harus dilalui antara lain adalah tahap pencatatan, yang diawali dari proses identifikasi transaksi, analisis transaksi, pencatatan transaksi ke dalam jurnal, posting ke buku besar, penyusunan neraca saldo, penyusunan jurnal penyesuaian, penyusunan neraca saldo setelah penyesuaian, penyusunan laporan keuangan, penyusunan jurnal penutup,penyusuna neraca saldo setelaah penutupan dan penyusunan jurnal balik, Tapi disayangkan hasil proses pencatatan , pengikhtisaran dan pelaporan sudah tersajikan namun banyak mahasiswa yang masih belum paham dalam membacanya dan menganalisis laporan keuangan tersebut, sementara laporan keuangan tersebut sangat penting untuk mengukur 
Liabilities Jurnal Pendidikan Akuntansi

e-ISSN 2620-5866

Volume 2. No.3 Desember 2019 (186-200)

Doi 10.30596/liabilities.v2i3.3770

kinerja menejerial, dan dapat digunakan untuk mengembagkan usaha seperti fasilitias kredit yang diberikan bank. Menurut mega Angita sari dari hasil penelitian (2018) banyak faktor yang mempengaruhi hasil belajar akuntansi mahasiswa yang rendah antar lain adalah faktor kemandirian, dimana dalam hasil penelitian mahasiswa kurang dalam memiliki kecakapan dalam menyelesaikan persoalan akuntansi, apabila diberikan soal mahasiswa masih banyak meminjam jawaban dari teman, dan kalau merasa kesulitan mahasiswa tidak mengerjakan soal yang diberikan oleh dosennya. Selain hal tersebut rendah hasil belajar mahasiswa disebabkan faktor ektern, yaitu dimana pembelajaran yang dilakukan tidak melihat kebutuhan mahasiswa dan pembelajaran hanya berorientasi pada target kurikulum. Kurangnya konsep teori yang dimiliki oleh mahasiswa perlu dilakukan merubah pola pembelajaran yang tadinya pembelajaran dilakukan berorientasi pada target kurikulum maka,dirubah pola pembelajaran dengam mengunakan model pembelajaran yang berorientasi kemahasiswa, sehingga mahasiswa dapat terbimbing baik dalam menyelesaikan masalah yang dihadapinya. Model pembelajaran Scoffolding

merupakan model pembelajaran yang dapat membantu mahasiswa dalam memecahkan persoalan yang dihadapi.Menurut Wood ( 2011: 167) .Scoofolding diartikan sebagai dukungan pembelajaran kepada peserta didik untuk membantu mahasiswa menyelesaiakan proses belajar yang tidak dapat diselesaikan sendiri.

Model pembelajaran scoffolding menurut Adinegara (2010:1) adalah merupakan model pembelajaran yang memberikan sejumlah besar bantuan kepada anak pada tahap-tahap awal pembelajaran kemudian sianak akan mengambil alih langsung tanggung jawab setelah ia dapat melakukan persoalan yang dihadapinya. Untuk mendukung pembelajaran tersebut perlu didukung oleh strategi pembelajaran sehingga anak dapat beraktifitas, dan leluasa dalam menerima pembelajaran dari pengajarnya, bagaimana pembelajaran yang berlangsung dapat menyenangkan magi mahasiswa. Salah satu pembelajaran yang dapat membantu mahasiswa adalah pembelajaran.

Pembelajaran analisis ratio keuangan dengan model scoffolding adalah suatu pembelajaran yang dilakukan untuk membantu mahasiswa dalam menyelesaikan masalah pembelajaran 
Liabilities Jurnal Pendidikan Akuntansi

e-ISSN 2620-5866

Volume 2. No.3 Desember 2019 (186-200)

Doi 10.30596/liabilities.v2i3.3770

dengan terbimbing dan beangsur-angsur

mahasiswa akan lebih mandiri dalam

menyelesaikan tugas-tugasnya.

Berdasakan hal tersebut yang menjadi tujuan dalam penelitian ini adalah :

1. Untuk menemukan bukti empiris dari penerapan pembelajaran analisa laporan keuangan dengan menggunakan model scofolding

2. Untuk meningkatkan Aktivitas Mahasiswa dalam pembelajaran analisa laporan keuangan dengan model pembelajaran Scoffolding.

3. Untuk mengetahui peningkatan hasil belajar mahasiswa terhadap pembelajara analisa laporan keuangan dengan menggunakan model scoffolding.

Pembelajaran secara simpel dapat diartikan sebagai produk interaksi berkelanjutan antara pengembangan dan pengalaman hidup. Pembelajaran dalam makna kompleks adalah usaha sadar dari seorang guru untuk membelajarkan siswanya (mengarahkan interaksi siswa dengan sumber belajar lainnya) dalam rangka mencapai tujuan yang diharapkan.

Suatu pembelajaran dikatakan efektif apabila memenuhi persyaratan utama keefektifan pengajaran, sebagai berikut.
a. Presentasi waktu belajar siswa yang tinggi dicurahkan terhadap KBM.
b. Rata-rata perilaku melaksanakan tugas yang tinggi diantara siswa.
c. Ketetapan antara kandungan materi ajaran dengan kemampuan siswa

(orientasi keberhasilan belajar)
diutamakan.

d. Mengembangkan suasana belajar yang akrab dan positif, mengembangkan struktur kelas yang mendukung butir (b), tanpa mengabaikan butir (d). (Trianto, 2009: 20).

\section{Model pembelajaran Scaffolding}

Pembelajaran Scaffolding adalah pembelajaran yang diberikan staf pengajar secara terbimbing atas ketidak pahaman dari anak didik terhadap tugas tugas yang diberikan, dalam hal ini pengajar memberikan bantuan dan motivasi agar sianak dapat melakukan penyelesaian tugas sampai ia bisa mandiri dan bertanggung jawab terhadap pekerjaannya. Menurut Gasong (2007) Scaffolding merupakan suatu pembelajaran dimana siswa diberi sejumlah bantuan selama tahap-tahap awal pembelajaran dan kemudian mengurangi bantuan tersebut dan memberikan kesempatan kepada siswa atau pelajar tersebut mengambil alih tanggung jawab yang semakin besar setelah mampu mengerjakannya sendiri berdasarkan pendapat gasong pembelajaran socffolding merupakan bantuan belajar apa bila bantuan tersebut masih diperlukan oleh siswa dan apabila siswa tersebut sudah memahaminya secara berangsur-angsur ia bantuan tersebut akan hilang dengan sendirinya, dan si anak 
Liabilities Jurnal Pendidikan Akuntansi

e-ISSN 2620-5866

Volume 2. No.3 Desember 2019 (186-200)

Doi 10.30596/liabilities.v2i3.3770

mampu secara mandiri untuk mengerjakan segala persoalan yang ia hadapi. Jadi dalam hal ini pembelajaran scoffolding adalah pembelajaran yang berlandaskan konstruktivismeyaitu mendorong siswa untuk aktif dalam menciptakan pengembangan pengetahuannya dan berinteraksi terhadap lingkungan. Disamping itu Pembelajaran Scaffolding didasarkan pada teori Vygotsky tentang konsep pembelajaran dengan bantuan, Menurut teori ini, fungsi-fungsi mental sangat dibutuhkan untuk mengarahkan kemampuan berpikir dengan menggunakan alat-alat atas kemampuan yang ia miliki.

Secara umum, Gasong (2007) mengemukakan pembelajaran scaffolding dengan langkah-langkah sebagai berikut :

1. Menjelaskan materi pembelajaran.

2. Menentukan Zone Of Proximal Development (ZPD) atau level perkembangan siswa berdasarkan tingkat kognitifnya dengan melihat nilai hasil belajar sebelumnya.

3. Mengelompokkan siswa menurut ZPDnya.

4. Memberikan tugas belajar berupa soalsoal berjenjang yang berkaitan dengan materi pembelajaran.

5. Mendorong siswa untuk bekerja dan belajar menyelesaikan soal-soal secara mandiri dengan berkelompok.

6. Memberikan bantuan berupa bimbingan, motivasi, pemberian contoh, kata kunci atau hal lain yang

dapat memancing siswa ke arah kemandirian belajar.

7. Mengarahkan siswa yang memiliki ZPD yang tinggi untuk membantu siswa yang memilki ZPD yang rendah.

8. Menyimpulkan pelajaran dan memberikan tugas-tugas

9. Selain dari pendapat ahli tersebut diatas secara pembelajaran scaffolding dapat ditempuh melalui tahapan berikut:

10. Melaksanakan asesmen kemampuaan awal dan taraf perkembangan setiap siswa untuk menentukan Zone of Proximal Development (ZPD), yakni wilayah perkembangan siswa yang masih berpotensi dan berpeluang untuk ditingkatkan dan dioptimalkan melalui bantuan guru, teman, atau lingkungan pembelajaran tertentu, termasuk di dalamnya pemanfaatan teknologi .

11. Menjabarkan tugas-tugas dan aktivitas belajar secara rinci sehingga dapat membantu siswa melihat zona yang perlu di-scaffold.

12. Menyajikan struktur/tugas belajar secara jelas dan bertahap sesuai taraf perkembangan siswa, yang dapat dilakukan melalui: penjelasan, dorongan (motivasi), dan pemberian contoh (modeling).

13. Mendorong siswa untuk menyelesaikan tugas belajar secara mandiri.

Sementara itu, Applebee dan Langer mengidentifikasi 5 (lima) langkah pembelajaran scaffolding yaitu:

1. Intentionally; mengelompokkan bagian kompleks yang hendak dikuasai siswa menjadi beberapa bagian yang spesifik dan jelas dan 
merupakan satu kesatuan yang utuh untuk mencapai kompetensi secara utuh.

2. Appropriateness; memfokuskan pada pemberian bantuan pada aspek-aspek yang belum dikuasai siswa secara maksimal.

3. Structure; memberikan model agar siswa dapat belajar dari model yang ditampilkan. Model tersebut dapat diberikan melalui proses berfikir, diverbalkan dalam katakata, atau melalui perbuatan. Kemudian, siswa diminta untuk menjelaskan apa yang telah dipelajari dari model tersebut.

4. Collaboration; melakukan kolaborasi dan memberikan respons terhadap tugas yang dikerjakan siswa.

5. Internalization: memantapkan pemilikan pengetahuan yang dimiliki siswa agar dikuasainya dengan baik dan menjadi bagian dari dirinya.

Dari langkah-langkah tersebut, inti pembelajaran scaffolding sesungguhnya terletak pada tahap structure dan tingkat kesuksesan penerapannya akan banyak ditentukan dari penentuan Zone of Proximal Development yang akan dibantu.

\section{METODE PENELITIAN}

Penelitian ini menggunakan metode tindakan kelas yaitu suatu metode yang melakukan penerapan pemeblajaran di kelas mulai dari perencanaan, pelaksanaan Tindakan, Observasi dan melakukan refleksi. Dalam hal ini peneliti mencoba penerapan langsung terhadap pembelajaran yang akan dilakukan dengan mengunakan model pembelajaran Scoffolding.

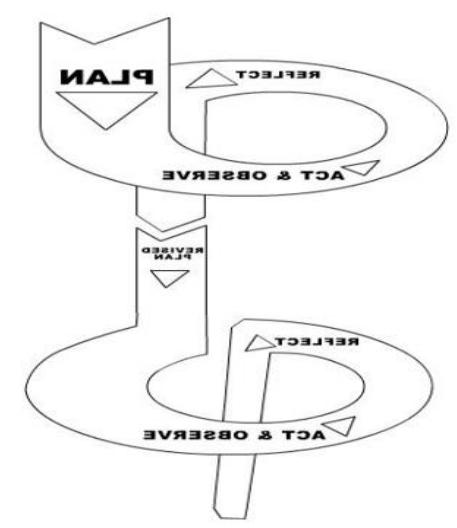

Gambar:

Rancangan Penelitian menurut Model Kemmis dan Taggart (2012: 11)

\section{HASIL PENELITIAN DAN PEMBAHASAN}

\subsection{Kondisi Awal Kelas}

Sebelum penelitian dilakukan, peneliti melakukan survey pendahuluan terhadap jumlah mahasiswa dan karakteristik mahasiswa dari jenis kelamin dan kemampuan awal yang mereka pahami dari analisis ratio keuangan, berdasarkan hasil survey dan pre tes yang peneliti lakukan maka diperolehlah data sebagai berikut : 
Liabilities Jurnal Pendidikan Akuntansi

e-ISSN 2620-5866

Volume 2. No.3 Desember 2019 (186-200)

Doi 10.30596/liabilities.v2i3.3770

Tabel I. Jumlah Mahasiswa berdasarkan Kelas

\begin{tabular}{|c|c|c|}
\hline No & $\begin{array}{c}\text { Kelas } \\
\text { /Semester }\end{array}$ & Jumlah mahasiswa \\
\hline 1 & VII A/Pagi & 40 \\
\hline 2 & VII B/Pagi & 12 \\
\hline 3 & VII A/Sore & 5 \\
\hline 4 & VIIA/Malam & 3 \\
\hline & Jumlah & 60 orang \\
\hline
\end{tabular}

Berdasarkan jumlah mahasiswa diatas, peneliti mengambil subjek penelitian untuk dilakukan tindakan adalah jumlah mahasiswa yang terbanyak yaitu mahasiswa Semester VII A/pagi sebanyak 40 orang,

Pada pertemuan awal yaitu pertemuan I , peneliti melakukan tes awal untuk melihat kemampuan mahasiswa dalam menganalisa laporan keuangan,. Tes diberikan dalam bentuk tes objektif sebanyak 20 Soal, dari hasil jawaban mahasiswa pada tes awal di peroleh hasil sebagai berikut:

Tabel 2.Hasil Tes Awal

\begin{tabular}{|l|l|c|c|c|}
\hline No & $\begin{array}{c}\text { Hasil } \\
\text { belajar }\end{array}$ & $\begin{array}{c}\text { Jumlah } \\
\text { mahasiswa }\end{array}$ & $\%$ & Ket \\
\hline 1 & $80-100$ & 0 & & $\begin{array}{c}\text { Sangat } \\
\text { tinggi }\end{array}$ \\
\hline 2 & $60-79,999$ & 7 & $17,5 \%$ & Tinggi \\
\hline 3 & $40-59,999$ & 26 & $65 \%$ & Cukup \\
\hline 4 & $20-39,999$ & 7 & $17,5 \%$ & Sedang \\
\hline 5 & $0-19,9999$ & 0 & & Rendah \\
\hline & Jumlah & 40 orang & & \\
\hline
\end{tabular}

Berdasakan tabel diatas menunjukkan bahwa nilai mahasiswa didominasi dalam katagori cukup, yaitu sebanyak $65 \%$ yang mendapatkan nilai 40-59,99, mengingat jumlah yang terbesar adalah dalam katagori cukup maka peneliti perlu melakukan tindakan sesuai dengan keadaan mahasiswa tersebut. Sebelum melakukan tindakan sesuai dengan penelitian tindakan kelas maka langkah awal adalah melakukan kegiatan perencanaan,pelaksaan, observasi dan refleksi.

\subsection{Upaya peningkatan Pembelajaran analisa ratio keuangan dengan model scoffolding}

Merujuk kepada teori Gasong, dalam upaya peningkatan hasil belajar, pelaksanaan pembelajaran analisa ratio keuangan diawali dengan:

1. Menjelaskan materi pembelajaran yang akan disajikan, mengingat hasil tes yang diperoleh mahasiswa dari tes yang diberikan materi menganalisa laporan keuangan yang sangat sulit untuk memahaminya, oleh sebab itu penekanan dalam penelitian ini adalah berhubungan dengan materi analisa 
ratio keuangan yaitu, analisa likuiditas dan profitabilita, yang berhubungan dengan analisis neraca dana laba rugi.

2. Menentukan Zone Of Proximal Development (ZPD) atau level perkembangan siswa berdasarkan tingkat kognitifnya dengan melihat nilai hasil belajar sebelumnya. Dalam menetukan Zone Of proximal Delopment, peneliti mengelompokkan mahasiswa berdasarkan hasil tes awal yang diberikan, membagi mahasiswa menjadi 8 kelompok, dalam satu kelompok berjumlah 5 orang. Dari kelompok masing-masing mahasiswa diminta untuk mencari laporan keuangan, yang mereka download dari masing-masing android yang mereka miliki.setelah itu Memberikan tugas belajar berupa soal-soal berjenjang yang berkaitan dengan materi pembelajaran,Dimulai dengan pengamatan dari laporan neraca dan laba rugi, sampai dengan menghitung likuiditas dan profitabilitas, sesuai dengan rumus yang sudah diberikan
sebelumnya.Pada pelaksanaan mengumpulkan informasi dalam pencarian laporan keuangan berdasakan pengamatan ,situasi kelas sangat tenang karena mahasiswa asyik dengan androidnya untuk melakukan pengamatan, dan ada bebearapa orang yang bertanya, atas ketidak pahaman mereka. Ditengah kesibukan mereka, Dosen memberikan motivasi mendorong mahasiswa untuk bekerja dan belajar menyelesaikan soal-soal secara mandiri dengan berkelompok.

3. Dosen memberikan bantuan berupa bimbingan, motivasi, pemberian contoh, kata kunci atau hal lain yang dapat memancing siswa ke arah kemandirian belajar dan mengarahkan siswa yang memiliki ZPD yang tinggi untuk membantu siswa yang memilki ZPD yang rendah

\subsection{Hasil Kerja Mahasiswa Dari Peroses Perhitungan Dan Analisis Likuiditas.}


Liabilities Jurnal Pendidikan Akuntansi

e-ISSN 2620-5866

Volume 2. No.3 Desember 2019 (186-200)

Doi 10.30596/liabilities.v2i3.3770

\section{Ekshibit B/1}

PT JAKARTA KYOEI STEEL WORKS Tbk

LAPORAN POSISI KEUANGAN ( NERACA)

UNTUK SEMBIL.AN BULAN YANG BERAKHIR

PADA TANGGAL-TANGGAL

30 SEPTEMBER 2017 DAN 31 DESEMBER 2016

ASET

ASET LANCAR

Kas dan setara kas

Piutang Usaha

Phak ketiga

( setelah dikurangi penyisihan piutang ragu-ragu

tanggal 30 September 2017 dan 31 Desember 2018 masing.

masing $R p$ 8,282,619,098, - dan $R p$ 8,282, 819,098,- )

Phak yang Berelasi

( seteleh dikurangi penyisihan piutang ragu-ragu

tanggal 30 September 2017 dan 31 Desember 2018 masing.

masing Rp 38,714,549,860,- dan Rp 38,714,549,880,- )

Piutang Lain-lain

Persediaan

Uang Muka Pembelian

Pajak dibayar dimuka

Biaya dibayar di muka dan aset lancar lainnya

Jumlah Aset Lancar

ASET TIDAK LANCAR

Piutang Pihak yang Berelasi

( setelah dikurangi penyisihan piutang ragu-ragu

tanggal 30 September 2017 dan 31 Desember 2016 masing.

masing Rp 36.267, 186.015. - dan Rp 36.267.186.015)

Aset pajak tangguhan

Aset Tetap

( setelah dikurangi penyishan piutang raguragu

tanggal 30 September 2017 dan 31 Desember 2016 masing-

masing $R p$ 22,876,763,340,- dan $R p 22,677,089,003$ )

Taghan $p 3 j a k$ penghasilan

Aset yang tidak digunakan dalam usaha

Uang jaminan

Jumlah Aset Tidak Lancar

JUMLAH ASET
Catatan

30 September 2017

$$
\mathrm{Rp}
$$

31 Desember 2016

$2.0,3 \quad 11.532 .920 .022$

9.317 .571 .508

2. .4 .4

1.517.825.847

9.519 .880 .818

\begin{tabular}{cr}
$2.6,5$ & 71.004 .438 .054 \\
$2 . d, 6$ & 15.000 .000 \\
$2 . e .7$ & 14.346 .024 .723 \\
& 104.307 .274 \\
2.1 .8 & 314.002 .726 \\
8 & 1.254 .673 .731 \\
\hline
\end{tabular}

100.179 .182 .377

71.482 .049 .208

5.911 .400

20.403.235.728

2.730 .968 .900

3.624 .373 .822

36.208 .612

117.120 .188 .198

$2 . b, 30, c \quad 61.898 .568 .654$

2.1 $\quad 39.023 .600 .747$

63.280.057.500 39.023.800.747

2.f.10 $\quad 45.002 .286 .802$

2.1 $\quad 3.624 .373 .822$

2.9.11 7.835.282.403

12

497.218 .000

157.881 .320 .628

45.206.083.161

7.835 .282 .403

735.454 .000

158.081 .387 .811 
Liabilities Jurnal Pendidikan Akuntansi

e-ISSN 2620-5866

Volume 2. No.3 Desember 2019 (186-200)

\section{PT JAKARTA KYOEI STEEL WORKS Tbk 12 LAPORAN POSISI KEUANGAN (NERACA) UNTUK SEMBILAN BULAN YANG BERAKHIR PADA TANGGAL-TANGGAL 30 SEPTEMBER 2017 DAN 31 DESEMBER 2016}

\section{LABПITAS DAN EKUTIAS}

ШАВППAS JANGKA PENDEK

Utang Usaha

- Pihal ketiga

- Pihal yang berelasi

Utang Lain-lain

Catatan

30 September 2017

$\mathrm{Rp}$

31 Desember 2016

Rp

Utang Pajak

Biaya masil barus dibayar

Junlah Liabilitas Jangla Pendek:

LABПITAS IIDAK LANCAR

Utang Investor

Kewajiban Uang jasa karyawan

Utang Pemegang Saham

Pendapatan Diterima dinulka

Jumlah Liabilitas tidak lancar
$13 \quad 1.096 .870 .267$

$13 \quad 21.975 .717 .926$

$14 \quad 14.081 .035 .000$

15

16

9.352 .844

262.421 .286

37.425 .397 .323

2.p, 17

638.089.331.702

702.340 .581

$2 \mathrm{~m} 19$

30.d

14.783 .076 .300

31.d

11.955 .976 .740

665.530 .725 .323
12.457 .691 .833

22.302 .764591

22.481 .048 .386

2.539 .822 .828

1.523 .095 .213

61.304 .422 .851

638.089 .331 .702

758.583 .709

14.783.076300

653.630 .991 .711

\section{ERUITAS}

Modal Saham

Modal dasar terdiri dari 600.000 .000 saham.

dengan milai nouninal $R_{p} 500$,

ditenpatkan dan disetor peunh 150.000 .000 saham

Tambahan modal disetor pernih

\begin{tabular}{|c|c|}
\hline 75.000 .000 .000 & 75.000 .000 .000 \\
\hline 6.514 .524 .544 & 6.514 .524 .544 \\
\hline$(526.410 .134 .185)$ & $(523.268 .353 .097)$ \\
\hline$\overline{(444.895 .609 .641)}$ & (441.753.828.553) \\
\hline 258.060 .513 .005 & 273.181 .586 .009 \\
\hline
\end{tabular}

ЛМLAHШАВПTAS DANEKUTTAS

258.060 .513 .00

273.181 .586 .009 
Liabilities Jurnal Pendidikan Akuntansi

e-ISSN 2620-5866

Volume 2. No.3 Desember 2019 (186-200)

Doi 10.30596/liabilities.v2i3.3770

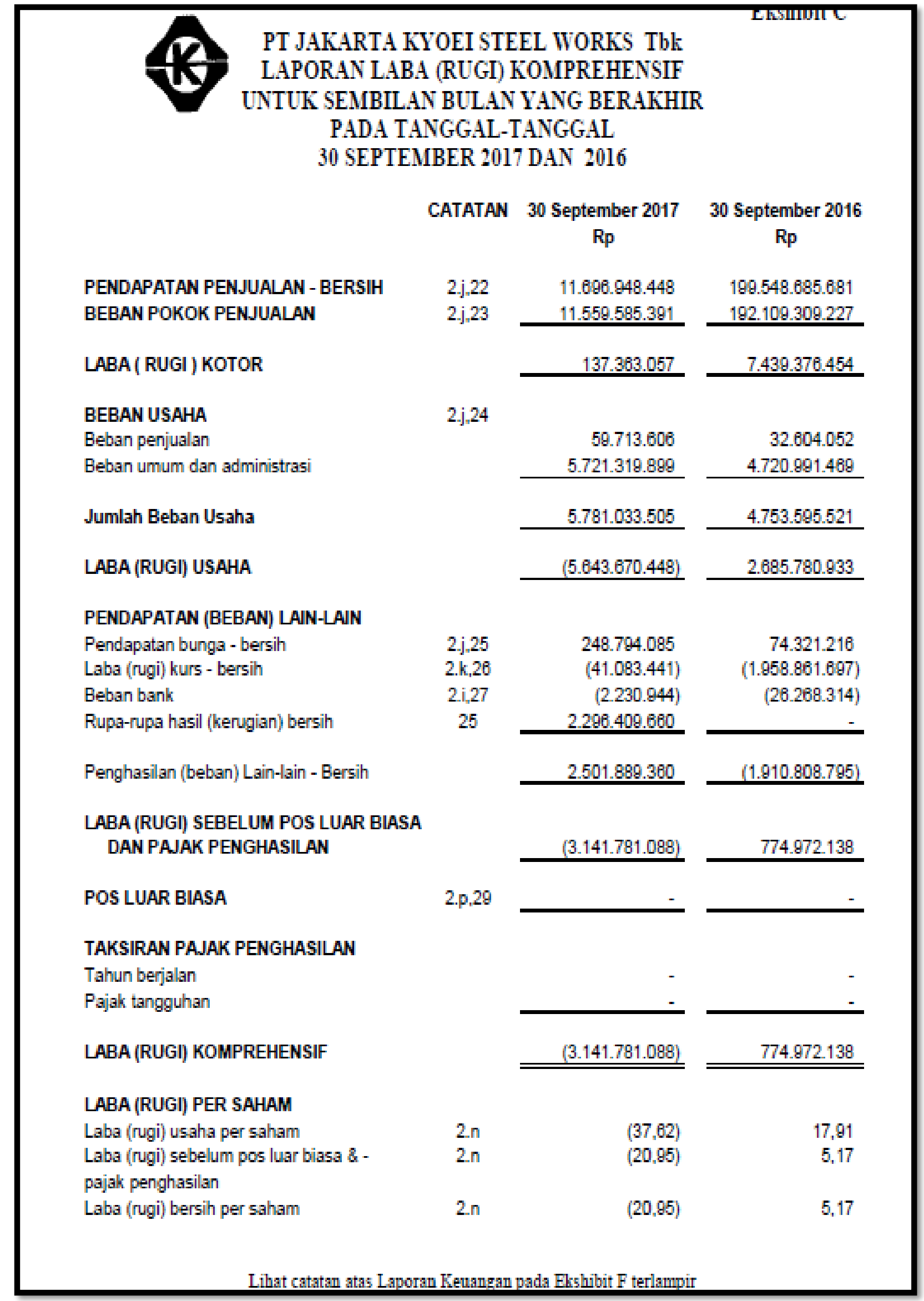


Liabilities Jurnal Pendidikan Akuntansi

e-ISSN 2620-5866

Volume 2. No.3 Desember 2019 (186-200)

Doi 10.30596/liabilities.v2i3.3770

1. Rasio Lancar (Current Rasio)

CurrentRatio

$=\frac{\text { Aktiva Lancar }}{\text { Hutang Lancar }}$

\begin{tabular}{|c|c|c|c|c|}
\hline $\begin{array}{l}\text { Ta } \\
\text { hun }\end{array}$ & $\begin{array}{l}\text { Aktiva } \\
\text { Lancar }\end{array}$ & $\begin{array}{l}\text { Hutang } \\
\text { Lancar }\end{array}$ & $\begin{array}{l}\text { Cu } \\
\text { rre } \\
\text { nt } \\
\text { Rat } \\
\text { io }\end{array}$ & $\begin{array}{l}\text { Stan } \\
\text { dar } \\
\text { Ind } \\
\text { ustr } \\
\text { i }\end{array}$ \\
\hline $\begin{array}{l}201 \\
6 \\
\end{array}$ & $\begin{array}{l}117.120 . \\
198.198 \\
\end{array}$ & $\begin{array}{l}61.304 \\
422.851\end{array}$ & $\begin{array}{l}1,9 \\
1\end{array}$ & \\
\hline $\begin{array}{l}201 \\
7 \\
\end{array}$ & $\begin{array}{l}100.179 . \\
192.377\end{array}$ & $\begin{array}{l}37.425 . \\
397.711\end{array}$ & $\begin{array}{l}2,6 \\
8\end{array}$ & $\begin{array}{l}2 \\
\text { kali }\end{array}$ \\
\hline \multicolumn{2}{|c|}{$\begin{array}{l}\text { Rata-Rata } \\
\text { Ratio }\end{array}$} & Cureent & $\begin{array}{l}2,2 \\
9\end{array}$ & \\
\hline
\end{tabular}

Analisis :

- Current ratio pada tahun 2016 sebesar 1,91 (dibulatkan jadi 2) yang artinya jumlah aktiva lancar sebanyak 2 kali utang lancar, atau setiap 1 rupiah utang lancar dijamin oleh 2 rupiah harta lancar atau 2:1 antara aktiva lancar dengan hutang lancar.

- Curret ratio pada tahun 2017 sebesar 2,68 (dibulatkan jadi 2,7) yang artinya jumlah aktiva lancar sebanyak 2,7 kali utang lancar atau setiap 1 rupiah utang lancar dijamin oleh 2,7 aktiva lancar atau 2,7 antara aktiva lancar dengan utang lancar.

- Berdasarkan tabel diatas dapat dilihat perhitungan current ratio PT. Jakarta Kyoei Tbk pada tahun 2016 sebesar 1.91 kali dan pada tahun 2017 sebesar
2,29 kali. Dengan demikian dapat diketahui bahwa pada tahun 2016-2017 rata rata current ratio yang dihasilkan perusahaan sebesar 2,29 kali, yang berarti diatas standar industri. Hal ini menunjukkan bahwa perusahaan mampu membayar kewajiban lancarnya dengan aktiva lancar yang dimiliki, untuk kinerja keuangan baik tahun 2016 dan 2017 dikatakan baik atau likuid tetapi belum tentu kondisi perusahaan sedang baik bisa saja karena kas tidak digunakan sebaik mungkin.

\section{Rasio Cepat (Quick Ratio)}

\section{QuickRatio}

$=\frac{\text { Aktiva Lancar }- \text { Persediaan }}{\text { Hutang Lancar }}$

\begin{tabular}{|c|c|c|c|c|c|}
\hline $\begin{array}{l}\mathrm{T} \\
\mathbf{a} \\
\mathrm{h} \\
\mathrm{u} \\
\mathrm{n}\end{array}$ & $\begin{array}{l}\text { Aktiv } \\
\text { a } \\
\text { Lanca } \\
\text { r }\end{array}$ & Persediaan & $\begin{array}{l}\text { Hutang } \\
\text { Lancar }\end{array}$ & $\begin{array}{l}\text { Quic } \\
\mathbf{k} \\
\text { Ratio }\end{array}$ & $\begin{array}{l}\text { Standar } \\
\text { Industri }\end{array}$ \\
\hline $\begin{array}{l}2 \\
0 \\
1 \\
6\end{array}$ & $\begin{array}{l}117.12 \\
0.198 . \\
198\end{array}$ & $\begin{array}{l}20.403 .235 .72 \\
8\end{array}$ & $\begin{array}{l}61.304 .422 .85 \\
1\end{array}$ & 1,17 & \\
\hline $\begin{array}{l}2 \\
0 \\
1 \\
7\end{array}$ & $\begin{array}{l}100.17 \\
9.192 . \\
377\end{array}$ & $\begin{array}{l}14.346 .024 .72 \\
3\end{array}$ & $\begin{array}{l}37.425 .397 .71 \\
1\end{array}$ & 1,00 & 1,5 kali \\
\hline \multicolumn{4}{|c|}{ Rata-Rata Quick Ratio } & 1,09 & \\
\hline
\end{tabular}

Analisis :

Berdasarkan tabel diatas dapat dilihat quick ratio pada PT.Jakarta Kyoei Tbk pada tahun 2016 sebesar 1,17 kali sedangkan pada tahun 2017 sebesar 1,00 
Liabilities Jurnal Pendidikan Akuntansi

e-ISSN 2620-5866

Volume 2. No.3 Desember 2019 (186-200)

Doi 10.30596/liabilities.v2i3.3770

kali hal ini berarti mengalami penurunan sebesar 0,17 kali dan rata-ratanya sebesar 1,09 kali. Jika rata-rata industri untuk quick ratio adalah 1,5 kali, maka keadaan perusahaan dikatakan tidak baik atau illikuid karena perusahaan harus menjual sediaannya untuk melunasi pembayaran utang lancar, padahal penjualan sediaan untuk harga yang normal relatif sulit, kecuali perusahaan menjual dibawah harga pasar, yang tentunya bagi perusahaan jelas menambah kerugian. Demikian pula sebaliknya, jika rasio perusahaan di atas rata-rata maka keadaan perusahaan lebih baik. Kondisi ini menunjukkan bahwa tidak harus menjual sedian bila hendak melunasi utang lancar, tetapi dapat menjual surat berharga penagihan hutang.

\section{Rasio Kas (Cash Ratio)}

$$
\text { CashRatio }=\frac{\text { Kas }}{\text { Hutang Lancar }} \times 100 \%
$$

\begin{tabular}{|c|c|c|c|c|}
\hline Tahun & Kas & Hutang Lancar & $\begin{array}{l}\text { Cash } \\
\text { Ratio }\end{array}$ & $\begin{array}{l}\text { Standar } \\
\text { Industri }\end{array}$ \\
\hline 2016 & 9.317 .571 .509 & 61.304 .422 .851 & 15,2 & \multirow{3}{*}{$50 \%$} \\
\hline 2017 & 11.532 .920 .022 & 37.425 .397 .711 & 30,8 & \\
\hline \multicolumn{3}{|c|}{ Rata-Rata Cash Ratio } & 23,0 & \\
\hline
\end{tabular}

\section{Analisis:}

Berdasarkan tabel diatas dapat dilihat bahwa cash ratio PT.Jakarta Kyoei Tbk pada tahun 2016 sebesar 15,2\% dan pada tahun 2017 sebesar 30,8\% dengan ratarata sebesar $23 \%$. Hal ini menunjukkan semakin kecil kemampuan perusahaan untuk melunasi kewajiban finansial yang disebabkan berkurangnya kas perusahaan dan diikuti semakin meningkatnya hutang lancar. Artinya perusahaan tidak mampu menjamin kewajiban jangka finansialnya karena cash ratio perusahaan di bawah standar industri yang menandakan bahwa perusahaan dikatakan tidak baik. Namun, kondisi rasio kas terlalu tinggi juga kurang baik karena manajemen belum melakukan pengelolaan secara baik ada dana yang menganggur atau yang tidak atau belum digunakan secara optimal dan tentu saja ini dapat merugikan perusahaan.

\section{Rasio Perputaran Kas (Cash Turn Over)}

\section{Cash Turn Over $=\frac{\text { Penjualan Bersih }}{\text { Modal Kerja Bersih }} \times 100 \%$}

\begin{tabular}{|l|l|l|l|l|}
\hline Tahun & $\begin{array}{l}\text { Penjualan } \\
\text { Bersih }\end{array}$ & $\begin{array}{l}\text { Modal Kerja } \\
\text { Bersih }\end{array}$ & $\begin{array}{l}\text { Sta } \\
\text { Cash } \\
\text { Over } \\
\text { Ovda }\end{array}$ & $\begin{array}{l}\text { r } \\
\text { Ind } \\
\text { ustr } \\
\text { i }\end{array}$ \\
\hline 2016 & $\begin{array}{l}199.548 .685 . \\
681\end{array}$ & $\begin{array}{l}75.000 .000 .0 \\
00\end{array}$ & 2,66 & \multirow{1}{1}{10} \\
2017 & $\begin{array}{l}11.696 .948 .4 \\
48\end{array}$ & $\begin{array}{l}75.000 .000 .0 \\
00\end{array}$ & 0.16 & $\%$ \\
\cline { 1 - 3 } & \multicolumn{2}{|l|}{ Rata-Rata Cash Turn Over } & $\mathbf{1 , 4 1}$ & \\
\hline
\end{tabular}

Analisis :

Berdasarkan tabel diatas Inventory to NWC perusahaan pada tahun 2016 dan 2017 dikatakan kurang baik karena masih cukup jauh dari rata-rata industri yaitu sebesar $2,66 \%$ dan $0,16 \%$ dengan ratarata $1,41 \%$. Hal ini dapat dikatakan ketersediaan kas tidak mencukupi untuk membayar tagihan dan biaya-biaya yang 
Liabilities Jurnal Pendidikan Akuntansi

e-ISSN 2620-5866

Volume 2. No.3 Desember 2019 (186-200)

Doi 10.30596/liabilities.v2i3.3770

berkaitan dengan penjualan. Dapat diartikan kas yang tertanam pada aktiva yang sulit dicairkan dalam waktu singkat sehingga perusahaan harus kerja keras dengan kas yang lebih sedikit. Ini berarti perusahaan tidak memiliki kemampuan yang lebih besar untuk menutupi biayabiaya perusahaan.

\section{Inventory to NWC}

\section{InventorytoNWC Persedian \\ $=\overline{\text { Aset Lancar - Hutang Lancar }}$ $\times 100 \%$}

\begin{tabular}{|l|l|l|l|l|l|}
\hline $\begin{array}{l}\text { Ta } \\
\text { hu } \\
\text { n }\end{array}$ & Persediaan & Aset Lancar & $\begin{array}{l}\text { Hutang } \\
\text { Lancar }\end{array}$ & $\begin{array}{l}\text { Inve } \\
\text { ntor } \\
\text { y to } \\
\text { NW } \\
\text { C }\end{array}$ & $\begin{array}{l}\text { Standar } \\
\text { Industri }\end{array}$ \\
\cline { 1 - 4 } 20 & $\begin{array}{l}20.403 .235 .72 \\
16\end{array}$ & $\begin{array}{l}117.120 .198 . \\
198\end{array}$ & $\begin{array}{l}61.304 .422 .8 \\
51\end{array}$ & 0.36 & \multirow{2}{*}{$12 \%$} \\
\hline $\begin{array}{lll}20 \\
17\end{array}$ & 14.346 .024 .72 & $\begin{array}{l}100.179 .192 . \\
377\end{array}$ & $\begin{array}{l}37.425 .397 .7 \\
11\end{array}$ & 0,22 & \\
\hline \multicolumn{2}{|l|}{ Rata-Rata Inventory to NWC } & $\mathbf{0 , 2 9}$ & \\
\hline
\end{tabular}

Analisis :

Dapat dilihat tabel diatas bahwa inventory to NWC perusahaan pada tahun 2016 sebesar $0,36 \%$ dan pada tahun 2017 sebesar 0,22\%. Pada tahun 2016-2017 mengalami penurunan yang bisa dibilang drastis, dilihat rata-ratanya sebesar 0,29. Keadaan perusahaan dapat dikatakan kurang baik karena masih dibawah ratarata industri. Hal ini berarti aktiva lancar kurang besar atas kewajiban lancar untuk mampu melindungi perusahaan dari ancaman perubahaan yang tidak menguntungkan dalam persediaan. Artinya modal kerja perusahaan kurang baik dalam menciptakan penjualan sehingga tidak dapat menambah saldo finansial perusahaan.

\subsection{Hasil Pembelajaran Setelah Pe;aksanaan Pembelajaran.}

Setelah pelaksanaan pembelajaran, untuk mengukur kemampuan mahasiswa maka dilakukan tes, hasil tes tersebut adalah sebagai berikut :

Tabel 2.Hasil Tes

\begin{tabular}{|c|c|c|c|c|}
\hline No & $\begin{array}{c}\text { Hasil } \\
\text { belajar }\end{array}$ & $\begin{array}{c}\text { Jumlah } \\
\text { mahasiswa }\end{array}$ & $\%$ & Keterangan \\
\hline 1 & $80-100$ & 10 & $25 \%$ & Sangat tinggi \\
\hline 2 & $60-79,999$ & 22 & $55 \%$ & Tinggi \\
\hline 3 & $40-$ & 5 & $12,5 \%$ & Cukup \\
\hline 4 & $20-39,999$ & 3 & $7,5 \%$ & Sedang \\
\hline 5 & $0-19,9999$ & 0 & 0 & Rendah \\
\hline & Jumlah & 40 orang & & \\
\hline
\end{tabular}

Berdaskar tabl diatas $75 \%$ mahasiswa memperoleh hasil belajar yang sangat tinggi, dan $50 \%$ mahasiswa memperoleh hasil belajar yang tinggi.

\section{.KESIMPULAN DAN SARAN}

\section{A. Kesimpulan}

Berdasarkan uraian dari pembahasan pada penelitian ini, maka dapat diambil kesimpulan sebagai berikut :

1. hasil yang diperoleh dari 40 orang masiswa yang mencapai diatas katagori tinggi sebanyak $80 \%$ dan nilai rata-rata kelas 81 .

2. Bahwa adanya peningkatan hasil belajar dari tes awal yang terjadi

\section{B. Saran}

Bagi dosen, khususnya dosen akuntansi dapat menerapkan model pembelajaran scaffolding karena model ini dapat meningkatkan hasil belajar mahasiswa 
dan kemandirian mahasiswa dalam menyelesaikan tugas-tugas apabila ada bimbingan dari dosen yang bersangkutan.

\section{DAFTAR PUSTAKA}

Abu Ahmadi dan Joko Tri Prasetya. Strategi Belajar Mengajar.Bandung.Pustaka setia

Ahmad Sudrajad.2008. http://Ahmad sudrajad.word press.com/2008/101/12/model pembelajaran-2.

Arikunto.2005. Managemen Penelitian.Jakarta.Rineka Cipta. Bayu Permana. 2009. Penerapan Pembelajaran dengan Pendekatan Scaffolding pada Pembelajaran Ekonomi untuk Meningkatkan Hasil Belajar Siswa Kelas X-2 SMA Laboratorium Universitas Negeri Malang. Skripsi Tidak Diterbitkan. Malang: FE Universitas Negeri Malang. Beny A.Pribady (2009) Model Desain Sistem pembelajaran.Jakarta. Dian Rakyat.

Danin Sudarwan.2006 Menjadi Komunitas Pembelajaran kepemimpinantransformasional dalam komunitas organisasipembelajaran.Jakarta.Bu mi Aksara.

E.Mulyasa.2006.Menjadi gur yang profesional.Bandung. PT.Remaja Rosda Karya.

Gasong, D,2007. Model Pembelajaran Konstruktifistik Sebagai Alternatif Mengatasi Masalah Pembelajaran (Online), (http:/www. Gerejatoraja.com./downloads/Mode 1 konstruktivistik.doc,diakses 15 Mei 2007

Hamalik.2004.Proses Belajar Mengajar. jakarta.Bumi Aksara.
Hamzah Ali, Muhlisavina (2014) Perencanaan dan Strategi pembelajaran Matematika.Raja Grafindo Persada.Jakarta.

Jumingan.2014. Analisis Laporan Keuangan.jakarta.Bumi Aksara.

Kemdiknas. 2008. Sosialisasi KTSP: Pengembangan Bahan Ajar. Jakarta: Kemdiknas.

Kunandar 2007. Guru profesional.Implementasi kurikulum (KTSP) dan sukses dalam sertifikasi guru.jakarta.Rajawali pers.

Nur, M \& Wikandari,P.R.2000. Pembelajaran Berpusat Pada Siswa dan Pendekatan Kontruktivitas dalam Pengajaran. Surabaya: Unesa

Pribadi, Benny \& Rosita, A. Tita, 2004. Prospek Komputer Sebagai Media Pembelajaran Interaktif dalam Sistem Pendidikan Jarak Jauh di Indonesia, Jurnal Pusat Studi Indonesia, Vol. 8 No. 2.

Suyanto .2013.Guru profesional,Strategi meningkatkan kualifikasi dan kualitas guru diera global.Erlangga.

Smaldino, Sharon. Lowter, Deborah. Russel, James D. 2011. Teknologi Pembelajaran dan Media untuk Belajar. Jakarta: Kencana Prenada Media Group.

Triton .2005. SPSS Terapan Riset StatistikParametrik.Yogjakarta.And i Offset.Jakarta.Rineka Cipta.

Waren,James Rade dkk.(2014).Pengantar Akuntansi.Adaptasi Indonesia.Jakarta.Salemba empat

http://catatankecilcalonakuntan.blogspot.c om/2012/06/belajar-akuntansidengan-lima-jari.html

https://akhmadsudrajat.wordpress.com/201 3/12/02/pembelajaran-scaffoldinguntuk-kesuksesan-belajar-siswa/ 